\title{
PLANNING THE ACTIVITIES OF INTELLECTUAL AGENTS IN THE ELECTRONIC COMMERCE SYSTEMS
}

Berko A. - Dr. Sc., Professor, Professor of Information Systems and Networks Department, Lviv Polytechnic National University, Lviv, Ukraine.

Vysotska V. - PhD, Associate Professor of Information Systems and Networks Department, Lviv Polytechnic National University, Lviv, Ukraine.

Lytvyn V. - Dr. Sc., Professor, Head of Information Systems and Networks Department, Lviv Polytechnic National University, Lviv, Ukraine.

Naum O. - Assistant of the Information systems and technologies department, Drohobych Ivan Franko State Pedagogical University, Drohobych, Ukraine.

ABSTRACT
Context. Today, e-commerce is one of the most active and promising segments of the global economy, characterized by steady growth of volumes and active improvement of tools and technologies. Intellectualization of e-commerce systems today is one of the main trends in their development and effective functioning in a competitive environment. One of the most promising means of solving this task category is the use of intellectual agents (IAs). The modern approach to modeling the decision support process, in particular, in e-commerce, uses the Boyd's loop principle, which involves repeated cycle repetition of four successive interrelated processes (stages): observation - orientation - decision-making - action. According to Boyd's hypothesis, the higher speed of the cycle and the accuracy of the evaluation of the stages of the cycle provide an advantage over the competitor.

Objective of the research is to develop tools for effective planning of actions of intellectual agents of e-commerce systems in a competitive environment based on ontologies, and to set the task of planning the actions of intellectual agents to the problem of dynamic programming.

Method. The mathematical support and method of action planning of IA based on adaptive ontologies are developed. This method can be used to effectively operate IA in a competitive environment of the SEC, which is modeled by Boyd's loop. Adaptive ontology is used to plan IA actions. To this end, we have added two scalar quantities (the importance of concepts and relationships) that are used to find an effective way to implement the IA plan in a generally accepted three-element tuple that defines ontology (a set of concepts, relationships, and their interpretation). Such an assessment of the ontology elements allows reducing the task of planning IA actions in a competitive environment to the task of dynamic programming.

Results. In the article the model of planning of actions of intellectual agents of electronic commerce systems using an ontological approach is constructed. The method of evaluation of actions of intellectual agents on the basis of adaptive ontologies is developed. Such an assessment makes it possible to reduce the task of scheduling actions to the task of dynamic programming.

Conclusions. Analysis of the results of IA actions can determine the causes of the formation of the target audience by a set of characteristics of the functioning of the SEC. By regulating the content, its uniqueness, the efficiency of its formation and its adequate management according to the individual needs of a regular user, one can model the boundaries of the target social audience and the number of unique visitors from search engines. In fig. 5-6 the results of the work of the developed systems in the form of charts are presented, from which it follows that in the presence of all types of IA significantly increases the volume of visits and unique users.

KEYWORDS: intelligent agent, ontology, planning, e-commerce.

\section{ABBREVIATIONS}

$\mathrm{B} 2 \mathrm{~B}$ is a Business-to-business;

$\mathrm{B} 2 \mathrm{C}$ is a Business-to-consumer;

$\mathrm{C} 2 \mathrm{~B}$ is a Consumer-to-business.

$\mathrm{KB}$ is a knowledge base;

IA is intelligent agent;

IS is an information system;

IP algorithmic paradigm;

IT is an information technology;

$\mathrm{SA}$ is a subject area;

SEC is system of electronic commerce.

\section{NOMENCLATURE}

$C$ is a set of concepts;

$R$ is the set of relations between concepts;

$F$ is the set of concepts and relationships interpretation axioms that set semantic constraints for a concepts and relationships system;

$S$ is set of AI states;

(C) Berko A. Y., Vysotska V. A., Lytvyn V. V., Naum O. M., 2018

DOI 10.15588/1607-3274-2018-4-14
$A$ is a set of actions;

Goal is set of target states;

Path is path from the initial state to the state of the goal

$W$ is weight of the importance of concepts $C$;

$L$ is weight of the importance of relations $R$;

$\Delta^{t}$ is some limit value of weight change of the concept, which depends on the ontology SA;

$\sigma_{i}$ is confidence;

$\sigma_{i C}$ is the old measure of confidence;

$U$ is information sources;

$T_{i j}$ is information resource;

$a_{j}^{k l}$ is the transition of IA from the state $S_{k}$ to the state of $S_{l}$, using the alternative $a_{j}$;

$g_{j}^{k l}$ cost of transition from state to state;

$v\left(a_{j}^{k l}\right)$ is evaluation of action $a_{j}^{k l}$ at a time;

$D_{i}$ is the domain of the property $x_{i}$;

$v\left(S_{k}\right)$ is estimate of the state of $S_{k}$;

$Z P$ is task of planning the activity of IA in the SEC; 
$E_{v}$ is a scalar quantity that coordinates resource expenditures with IA actions;

$E_{q}$ is a scalar quantity that agrees with the measure of the effect obtained with the actions of the IA;

$g_{i j}^{k}$ is the cost of resources for the transition from the state of $S_{i}$ to the state $S_{j}$, using the alternative $a_{k}$;

$r_{j}^{k}$ is the period of operation of the IA in the state $S_{j}$, in the alternative to $a_{k}$;

$r_{e}$ is desired period of operation of IA.

\section{INTRODUCTION}

Today, e-commerce is one of the most promising areas for the development of Internet systems and Internet technologies. The trend of steady growth of the ecommerce market has remained unchanged for over two decades and continues to be maintained. According to a study by Morgan Stanley [5], it is projected that the global e-commerce market in 2016 will exceed \$ 1 trillion in the USA. In Ukraine the total e-commerce market in 2015 compared to 2014 has increased by $37 \%$, and in 2016 it is forecast to grow by $27 \%$ [2]. Such active development of the industry causes additional competition and introduces new requirements to the participants of the e-commerce market. Unlike traditional trade, for which the main ways to increase competitiveness remain marketing approaches (price policy, expansion of the client base, the capture of new markets, change in the range, etc.) for e-commerce, the domination of technological solutions in improving market efficiency is typical. In the environment of e-commerce there is large number of factors that determine the behavior of elements in this environment, the way to make solutions and directly affect the effectiveness and quality of the results of the operation of IA. The description of such factors is stored in the KB, not in the database, since logical output plays an important role in the simulation of the IA's actions, which can be realized on the basis of knowledge about the software. The core of such a BP is the software ontology. Consequently, the development of methods and means of supporting the decision-making of the functioning of IA in the SEC using the ontological approach is an urgent area of research. The results of this set of tasks provide new opportunities for analyzing the IA solutions made in the competitive environment of ecommerce and their further adjusting. The main technological trends in the development of e-commerce systems and tools that increase their competitiveness in the market in 2018 are determined, such as: [4], [6]

1. Mobile technologies, which provide the active use of mobile devices to access e-commerce resources, advertising and electronic payments.

2. Multi-Channel is used for a wide range of different methods and means of communication between the ecommerce provider and the client.

3. Personalization is used for organization of the policy of interaction with the client based on his individual characteristics and needs. This is done by

(C) Berko A. Y., Vysotska V. A., Lytvyn V. V., Naum O. M., 2018 DOI 10.15588/1607-3274-2018-4-14 analyzing customer personal data from shopping history, forums, social networks and more.

4. Socialization is used for active communication between the e-commerce provider and clients using a variety of environments and IT.

5. Cloud Services are used to provide free access to the resources and proposals of the SEC without limiting client's place of residence, his time, IT and access facilities.

6. Big Data Technologies are used to involve the use of significant volumes of operational data of various content and format, obtained from a wide range of sources in the tasks of analysis and planning of the policy of the SEC.

7. Small Data Technologies are used to focus on the means of interaction with customers with the characteristics of a particular person by using personal data that is obtained in the process of communicating with the client.

8. The iBeacon technology uses close-range devices (Bluetooth, WiFi, NFC, etc.) to establish active contact with the customer at the time of his stay at a point of sale or service.

9. Intellectual IT is based on the application of methods and tools for processing knowledge and situational decision-making in the SEC.

The object of the research is the processes of supporting the decision-making of the functioning of IA in the SEC using ontological approach. The subject of the research is the methods of effective planning of IA activities in the SEC. The aim of the study is to develop tools for effective planning of IA activities in the SEC in a competitive environment based on ontologies, and to sum up the task of planning IA actions to the task of dynamic programming.

\section{PROBLEM STATEMENT}

There are two main ways to achieve the competitive advantage of SEC in competitive environments using IA [3], [7], [9]. The first way is to accelerate the OODA IA activity cycle. This allows the first to make decisions and forces competitors to respond in response to the imposed plan. The second way is to improve the quality of the decisions made, that is, to build a plan of action that is more responsive to a situation than a competitor's decision. One of the ways to improve the quality of solutions made by IA e-commerce a modern approach to building a BP on the basis of ontology can be to used [7], [8]. Formally, the ontology consists of terms (concepts) organized in taxonomy, their definitions and attributes, as well as the axioms associated with them and the rules of derivation [8]. Therefore, under the model of ontology $\mathrm{O}$ we understand the three forms

$$
O=<C, R, F>\text {. }
$$

The main attention in the article is focused on the planning of IA activities in the SEC (Boyd's loop orientation stage). The essence of the orientation of the AI is to find the Path from the initial state to the state of the goal, subject to the fulfillment of certain criteria. 
Typically, such criteria specify the rationality of the behavior of the IA, the essence of which is to find a Path in which transition costs are optimal, and the effect (the reaction of the external environment within which the IA functions) from such a transition is maximal [5-6]. Such rational behavior is similar to the well-known economic model of "price-quality", which makes it possible to reduce the task of constructing an action plan for IA to the category of two-criterion.

\section{REVIEW OF THE LITERATURE}

The intellectualization of the SEC, in the opinion of the authors, today is the most promising direction of their development in the coming years, as this way allows to change the principles of the functioning of e-commerce systems and tools in general. The introduction of intellectual IT involves the evolutionary transition of the SEC from the IP and IT to heuristic (intelligent systems). For systems constructed on this principle, there are the following features $[3,9]$ :

- flexibility, sensitivity to environmental indicators, self-organization;

- ability to learn;

- risks of errors;

- accumulation and use of prior knowledge;

- adaptation to changing environment.

The use of intelligent technologies for the construction and organization of activities of the SEC considerably expands the possibilities of their functioning in a competitive environment [10-16].

Today, one of the most popular methods of constructing complex intelligent systems that operate in competitive environments is the use of IA [3, 9]. Intelligent Agent is a software tool designed for selflocation, moving and playback and performing certain actions in a distributed network environment, functioning of which is in accordance with the principles of intelligent systems [3]. This means that the IA is able to identify the host environment and its changes, accumulate to apply knowledge (self-learning), make decisions, plan and perform actions in accordance with the situation [9]. The use of IA as an active mean of business provides the SEC with fundamentally new opportunities that enhance their competitiveness and the efficiency of their operation in a competitive environment.

The most common approach to organizing the functioning of IA e-commerce in a competitive environment today is a Boyle Loop type model [1]. Boyd's loop (cycle) is the concept of organizing the object's operation in a competitive environment, which involves the cyclic execution of a defined sequence of stages [1]. The completion of the Boyd Loop stages form a cycle, denoted by the acronym OODA [1,9], that consists of the following sequence of procedures:

1) Observation is the process of gathering information necessary for a decision in a particular situation;

2) Orientation which involves the processing of information obtained as a result of actions at the monitoring stage, using methods of analysis and synthesis;

3) Decision-making is determination of the best variant of the plan of action for its further realization;

4) Action is the final stage of the cycle, which involves the practical implementation of the chosen course or action plan.

\section{MATERIALS AND METHODS}

The use of IA as an active means of business provides the SEC with fundamentally new opportunities that enhance their competitive ability and efficiency in a competitive environment. The main functions of the IA for the SEC are presented in the form of the Use-Case Diagram (Fig. 1) [17-22].

In this way, it is possible to organize the functioning of the electronic commerce system through an intelligent agent, whose work is based on the use of adaptive ontology (Fig. 1). Ontology in this structure is the core of the knowledge base that describes the agent's activity in the competitive environment of e-commerce. An intelligent agent in this case serves as an advanced interface tool in the interaction of the e-commerce system with clients and partners in a market-based Internet environment. This provides a significant expansion of the functionality of such an interface by providing the intelligent agent of the system of additional capabilities.

The main functions of the intellectual agent of the ecommerce system include [23-31]:

- Maintenance of communications in the areas of "client-business", "business client" and "businessbusiness";

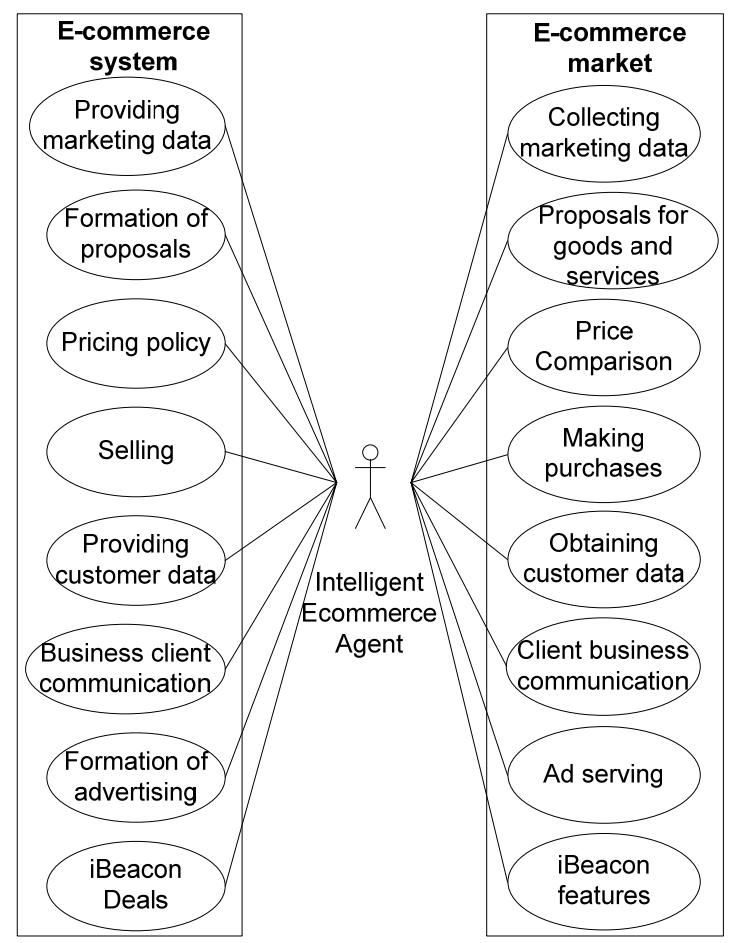

Figure 1 - A UML diagram of options for using an intelligent agent 
- collection of marketing data in the external environment about the situation on the market;

- Formation and distribution of offers of goods and services among customers and potential users of ecommerce systems;

- Data collection and comparison of prices for goods and services with analogues in the e-commerce market for the formation of the pricing policy of the system of electronic commerce;

- Realization of operations of purchase and sale of goods and services in the Internet environment;

- Obtaining customer data from the external environment and transferring them to the e-commerce system;

- Formation and targeting of advertising information from the system of electronic commerce to the client;

- Beacon (iBeacon) client interaction with short-range devices such as Bluetooth, WiFi, NFC, etc.

In addition to expanding the functionality, the use of the intelligent agent creates opportunities for increasing the efficiency of the operation of the e-commerce system by improving the quality of decision-making in a competitive environment [32-42]. By the nature of the tasks that are performed by the IA in the SEC, we will distinguish between the following categories (Fig. 2).

$-\mathrm{B} 2 \mathrm{C}$ of IA types is provide interaction between the SEC and the consumer of goods and services;

- C2B of IA types is provide interaction between consumers of goods and services from the SEC;

$-\mathrm{B} 2 \mathrm{~B}$ of IA types is provide interconnection between the SECs.

The task of planning the activity of IA in the SEC $Z P$ contains 3 components, $Z P=<S, A$, Goal $>$. For an effective planning of the e-commerce IA activity, an important element is the ability to evaluate the states and actions. For this purpose, it is expedient to use the model of adaptive ontology [6,14], which is defined by the expression of the species:

$$
\hat{O}=\langle\hat{C}, \hat{R}, F\rangle
$$

where $\hat{C}=\langle C, W\rangle, \quad \hat{R}=\langle R, L\rangle$. The essence of the proposed solution consists in narrowing the search space of the best-case scenario of e-commerce IA, which allows us to eliminate the ineffective and inappropriate solution

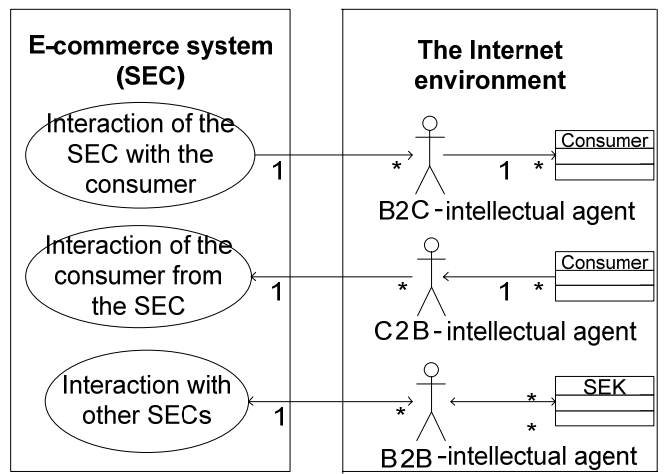

Figure 2 -Intelligent agent categories for e-commerce system how to improve the quality of the final result. The solution of the $Z P$ problem, in this case, is as follows:

- adaptive ontology concepts $\hat{C}=\left\{\hat{C}_{1}, \hat{C}_{2}, \ldots, \hat{C}_{m}\right\}$, adaptive ontology $\hat{O}$, which specify alternatives for the transition between states of the IA, give the weight $W_{k}$, $k=1,2, \ldots, m$;

- over time this weight varies depending on the degree of confidence $\sigma_{i}$ to the source of information on the basis of which alternative has been added to the ontology;

- those notions of the set $\hat{C}$, the increase in weights of which for a certain period does not exceed a certain threshold, $\Delta^{t}$ is removed.

- let at some time the weight of the concept $\hat{C}_{k}$ of the ontology Ô be equal to $W_{k}^{t}$. To increase the weight of the concepts, certain sources of information are used by $U$. That is, there are a plenty of information sources $U=\left\{U_{1}\right.$, $\left.U_{2}, \ldots, U_{m}\right\}$, each of which contains a plurality of resources $U_{i}=\left\{T_{i 1}, T_{i 2}, \ldots, T_{i p}\right\}$. The confidence measure for the source $U_{i}$ will be denoted as $\sigma_{i} \in[0,1]$, where $\sigma_{i}=0$ indicates a complete distrust of the source $U_{i}, \sigma_{i}=1$ is the maximum confidence in the source $U_{i}$. It is initially assumed that the measure of confidence of all sources is the same, and has no deviations in one direction or another, that is, $\sigma_{i}=0.5$, and in addition to the ontology, the concepts of the measure change. To assess the change in the confidence in the source, the following procedure is proposed: the new confidence measure $\sigma_{i H}$ to the source is calculated as $\sigma_{i H}=2 \cdot \sigma_{i C}-\sigma_{i C}{ }^{2}$, if the expert used source resources to supplement the ontology;

- the new measure is calculated as $\sigma_{i H}=\sigma_{i C}-\sigma_{i C}{ }^{2}$, if the expert did not use the resources from this source to supplement the ontology;

- if, after completing the ontology $\sigma_{i H}<\lambda$, such a source of information is not considered in the future (in practice, sufficient threshold values are considered to be $\lambda=0,1$, that is, when, after six consecutive attempts, resources of the source are not used to fill the ontology its measure of confidence takes the value $\sigma_{i H} \approx 0,099$, and such a source is excluded from further use in the processes of complementing the ontology);

- after performing all the stages of filling the ontology, the weights of each of the concepts $\hat{C}_{k}, k=1,2$, ..., $m$ are changed by the formula:

$$
W_{k}^{t+1}=W_{k}^{t}+\sum_{T_{i j} \otimes U_{i}} \sigma_{i},
$$

where the entry $T_{i j} \otimes U_{i}$ indicates that the $T_{i j}$ resource from $U_{i}$ source of information is used to fill the ontology;

- in the next step ontology excludes concepts for which the growth of confidence is insignificant, that is $W_{k}^{t+1}-W_{k}^{t}<\Delta^{t}$.

Performing such a sequence of steps allows you to reduce the search space of the best path (Path) in the IA actions. After the search space Path is narrowed, the twocriterion problem of choosing the transition path between two adjacent states can be reduced to a task with one criterion. To do this, we do the following: The set of 
concepts $\hat{C}$ is described by the characteristics (properties) of $X=\left\{x_{1}, x_{2}, \ldots, x_{M}\right\}$; the value of the property $x_{i}$. is denoted as $z_{i}=z\left(x_{i}\right) \in D_{i}$. The goal state of the Goal is determined by the fact that some subset of signs $X^{\prime} \subseteq X$ must reach certain values of $z\left(x_{i}\right.$, Goal $) \forall x \in X^{\prime}$. To select actions we will rely on the rationality of IA behavior in the SEC, that is, in an effort to minimize the cost of resources to achieve the state of the goal. Each action $a_{j}^{k l}$ equals a certain expense of IA resources $-g_{j}^{k l}$. In the tasks of improving the efficiency of the SEC in a competitive environment, each of the alternatives is characterized by resource costs (material, private, financial, etc.) and resulting effect (financial, marketing, time etc.). Information about alternatives, costs of operating resources is stored on an ontology. Estimates of the transition of IA from one state to another are directly proportional to

(1) cost of resources $v\left(a_{j}^{k l}\right)=E_{v} \cdot g_{j}^{k l}$, and

(2) for the resulting effect $q\left(a_{j}^{k l}\right)=E_{q} \cdot g_{j}^{k l}$.

In this view, the task of the IA is to minimize the values that characterize the SEEC's total costs in the selected way

$$
V^{*}=\sum_{(k, l) \in \operatorname{Path}(V)}^{n} v\left(a_{j_{k l}}^{k l}\right) \rightarrow \min ,
$$

and maximizing the resulting SEC effect

$$
Q^{*}=\sum_{(k, l) \in \operatorname{Path}(Q)}^{n} q\left(a_{j_{k l}}^{k l}\right) \rightarrow \max ,
$$

where $(k, l)$ specifies the transition path from the state $S_{k}$ to the state $S_{l}, j_{k l}$ the alternative number selected for such a transition, Path $(V)$ is the path for reducing the cost, $\operatorname{Path}(Q)$ is the way to increase the effect. Thus, in this way the task of planning the actions of IA in the SEC is reduced to a two-criterion optimization problem. Traditionally, such tasks are quite complex to solve, require the use of dynamic programming methods and do not always give the expected solution. The use of ontology in IA planning allows the heuristic approach that is based on pre-acquired knowledge that builds on such an oncology and continually updates and replenishes them in the processes of the functioning of an IA for building an effective plan of its action. In order to assess the reaction of the environment to the behavior of IA in the SEC, principles have been applied to stimulating learning [11]. This involves the following scheme of his actions:

- at each step the agent is in the state $s$ of some set of states $S$;

- in such a state, he chooses from an existing set of actions $A$ some action $a$;

- in response to this e-commerce environment informs the agent of the evaluation of the results of such an action and a new state;

- on the basis of the received IA builds an optimal plan of behavior, corresponding to the given criteria.

We denote $Q^{*}(S)$ the expected gain of the IA in the state $S ; \quad Y: S \times A \rightarrow Y$ is promotion functions; $T: S \times A \rightarrow S^{\prime}$ is functions of transition between states.

C Berko A. Y., Vysotska V. A., Lytvyn V. V., Naum O. M., 2018 DOI 10.15588/1607-3274-2018-4-14
The task is to maximize the winnings. In the real situation, at the beginning of the process, the IA is in absolute uncertainty, since no known reaction of the system to any actions, including transitions between states. According to the theory of stimulating learning [14], the optimal value of a state is the reward that we receive if the IA works best. This value can be defined as the solution of equations:

$$
Q^{*}=\max _{a \in A}\left(Y(S, a)+\gamma \sum_{\text {Path }} T\left(S, a, S^{\prime}\right) Q^{*}\left(S^{\prime}\right)\right) .
$$

If you know it, then the choice of the optimal strategy is carried out according to the formula:

$$
\pi^{*}(s)=\underset{a}{\arg \max }\left(Y(S, a)+\gamma \sum_{\text {Path }} T\left(S, a, S^{\prime}\right) Q^{*}\left(S^{\prime}\right)\right) .
$$

Traditionally, this problem is solved by an iterative method. Taking into account (4) and (5), we obtain a twocriterion problem. From a mathematical point of view, there is no ideal method or method for solving such problems. Each of them has its own advantages and disadvantages and the scope of application. Having analyzed the known methods, the method of the main component is chosen if the target functions (4) or (5) can be evaluated accordingly from below or from above; if it is impossible to evaluate them, then we use the complex criterion method. Thus we get one of three tasks:

$$
\begin{gathered}
\min V^{*}, Q^{*} \geq Q, \\
\max Q^{*}, V^{*} \leq V, \\
\min f=\frac{V^{*}}{Q^{*}} .
\end{gathered}
$$

Tasks (6)-(8) are multi-step optimization tasks, that is, the tasks of dynamic programming. In practice, solving such problems is complex enough, and is requiring considerable time and resource costs. Therefore, repeated repetition of such procedures for choosing an optimal IA action plan can significantly impede or disable its activities. An alternative way is to build an action plan based on previously obtained decisions that are stored in the BP. The basis of such a BP forms a special ontology. The use of ontology reduces task of constructing a plan to search for and evaluate conversion options based on predetermined descriptions, rules and criteria (Fig. 3).

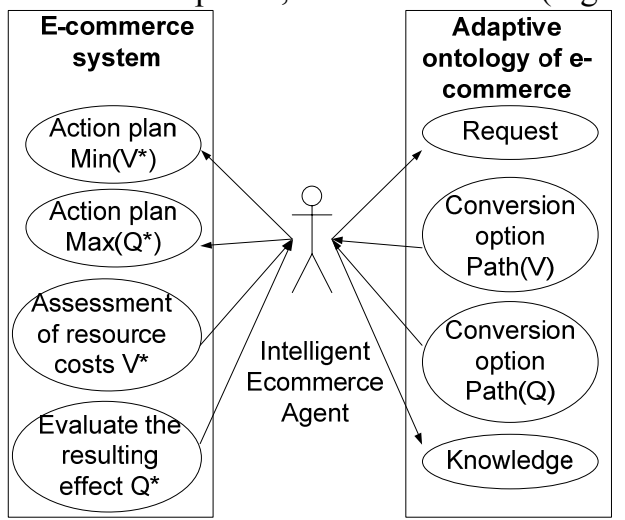

Figure 3 -Case diagram of using the intelligence agent when choosing an optimal action plan 
The use of the intellectual agent and the knowledge base on the basis of adaptive ontology allows you to move from solving the problem of dynamic programming to choosing a solution based on previously acquired knowledge. The work of the intellectual agent of the ecommerce system in this process is organized as follows.

1. IA generates a request for an ontology, which defines the type of e-commerce activity and criteria for optimality of the cost indices of $V^{*}$ resources and the effectiveness of $Q^{*}$.

2. As a result of the query, the intelligent receives transition options for constructing an optimal action plan to minimize resource costs - Path $(V)$ and maximize the $\operatorname{Path}(Q)$ effect.

3. SEC implements selected plans and performs an estimate of the optimality of the cost of resources $V^{*}$ and efficiency of $Q^{*}$.

4. The results of the evaluation system are passed to the agent, which, in the case of their compliance with the specified criteria, preserves the selected paths $\operatorname{Path}(V)$ and $\operatorname{Path}(Q)$ as optimal transitions for the specified type of action of the SEC.

5. In case of non-compliance of the results of the actions of the SEC with the given criteria of optimality, the intellectual agent initiates the updating of the adaptive ontology with new knowledge about optimal variants of transitions. An update is either performed by an expert or based on previously accumulated IA knowledge.

In general, this way of solving the problem of constructing an optimal IA action plan involves a significant reduction in the level of its formalization and the accuracy of the results. However, given that the use of large volumes of incomplete or inaccurate data and informal criteria is typical for the SEC, the use of traditional mathematical methods becomes rather difficult and often impossible. Therefore, the use of ontologies for constructing an IA action plan is justified in such circumstances by approach.

\section{EXPERIMENTS}

The module of functioning of IA planning of the SEC activity was developed [12]. Let the IA be in the state $S(0)$, there is some information resource $G$. Before the IA there is a task $P$ is to go to some target state of Goal, using this resource and software knowledge stored in its ontology: $P: S_{0} \stackrel{G, O}{\rightarrow}$ Goal. The period of operation of the IA $(r)$ is used to assess the states, and for the actions, the cost of resources $g$ for the transition from state to state.

Then the formula for choosing alternatives is presented as:

$$
o\left(a_{i j}^{k}\right)=\frac{r_{j}^{k}}{g_{i j}^{k}} .
$$

So for interaction of the SEC with the consumer it is necessary to solve three subtasks (identification, processing of the order, implementation of payments), the second of which is divided into nine subtasks (the formation of a consumer basket, the formation of (C) Berko A. Y., Vysotska V. A., Lytvyn V. V., Naum O. M., 2018 DOI 10.15588/1607-3274-2018-4-14 proposals for shares, receipt of confirmation of the order from the consumer, clarification of the methods payments, payment, clarification of delivery methods, registration of the order, formation of a notice to the consumer about the registration of the order).

Alternative solutions are used to solve each subtask. For the subtask of specifying the delivery methods you can choose one of three alternatives: mail, courier, self delivery. Information is stored in the ontology of ecommerce [13].

The rationality of activity planning is formulated as follows: how to maximize the resulting SEEK effect with minimal cost, taking into account that:

1) the main restrictive resource factor is the level of demand for goods and services that a particular SEC implements;

2) the target economy effect received by the user of the IA from the functioning of the SEC and possible losses from its incorrect functioning;

3) The costs of promoting the information resources of the SEC are known and determined by IT Internet marketing and SEO;

4) indicative terms of profitable functioning of the SEC for a specific category of goods or services for known (specified) promotional and other measures by Internet marketing tools and SEO technologies are known from expert assessments, norms, forecasts, for example, based on Google Analytics and tools statistics Google Adsense and Google AdWords.

So for the subtype of the formation of sales for goods or the formation of shares for the service in accordance with the forecasts for the decline in demand for them, the following rule has been used: IF ((Ends the seasonal period) OR (The number of sales is equal to or less than the threshold minimum) OR (The number of negative comments is greater or equal or (The number of failures / returns is greater or equal to the threshold minimum)) AND (There are no alternative solutions, goods or services) TO (Block the sale of goods and formulate a request moderator on his replacement).

KB details this rule through the system of refinement product rules, constructed in accordance with the Rete algorithm. For IA, there is important information that allows you to succeed in solving this problem, i.e.: information on new types of alternative products or services that are more in demand among potential customers; information on pricing policies for such alternative products in accordance with the capabilities of regular consumers (target audiences) of this specific SEC; information on more effective marketing technologies for the promotion of goods and services through the information resource of the SEC. To search for this information, analyze the information resources of the relevant SECs that have been in demand in recent years. The results are written in the developed ontology using the SWRL rules. In general, we get the following model of the problem: 


$$
\left[\begin{array}{l}
\Theta=\sum_{i=0}^{N-1} o_{i}\left(a_{i j}^{k}\right) \rightarrow \max , \\
r \geq r_{e}, \\
\sum_{i=0}^{N-1} g_{i j}^{k} \leq G,
\end{array}\right.
$$

where $r=\min _{j} r_{j}$.

The problem (9) can be solved by the method of functional equations, which is suitable for solving dynamic programming tasks. The use of adaptive ontologies in IA KB allows reducing the task of planning activities to the task of dynamic programming [14-15].

\section{RESULTS}

For the SEC without IA, the statistics of the visit are rather chaotic and uncontrolled (Fig. 4).

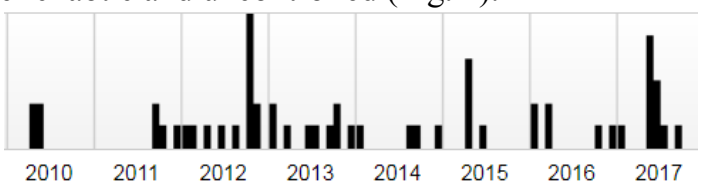

Figure 4 - An example of visiting the information resource (travelua.org) for Internet tourism

For a detailed analysis of the functioning of the SEC as an Internet newspaper and Internet journal, different systems with different types of IAs were developed and implemented, maintaining for each of them a different number of stages of the content lifecycle. That is, not all types of IAs have been developed for different implemented SECs or IAs have not been developed at all. Tabl 1 provides a list of implemented SECs indicating the availability of implemented IAs with maintenance of the content lifecycle.
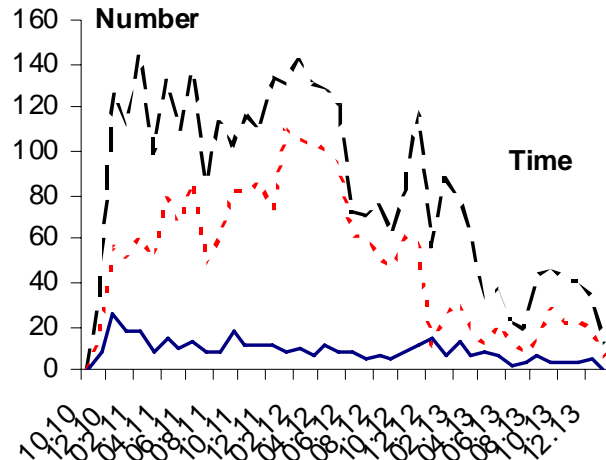

- - - Visiting information resource

- . - - - Visiting permanent users

Realization of commercial content

a
Table 1 - Implementation of various IAs in the SEC

\begin{tabular}{|c|c|c|c|}
\hline № & URL & Type & IA \\
\hline 1 & fotoghalereja-vysocjkykh.com & journal & C2B,B2C \\
\hline 2 & vgolos.com.ua & newspaper & C2B,B2C,B2B \\
\hline 3 & tatjana.in.ua & journal & B2C \\
\hline 4 & presstime.com.ua & newspaper & C2B,B2C \\
\hline 5 & www.autochip.vn.ua & journal & C2B,B2C \\
\hline 6 & kursyvalyut.com & newspaper & C2B,B2C,B2B \\
\hline 7 & dobryjranok.com & newspaper & C2B,B2C \\
\hline 8 & goodmorningua.com & newspaper & B2B \\
\hline 9 & зсш3львiв.in.ua & newspaper & C2B \\
\hline 10 & victana.lviv.ua & journal & С2B,B2C,B2B \\
\hline
\end{tabular}

Analysis of the results of IA actions can determine the causes of the formation of the target audience by the set of characteristics of the functioning of the SEC. By regulating the content, its uniqueness, the efficiency of its formation and its adequate management according to the individual needs of a regular user, one can model the boundaries of the target social audience and the number of unique visitors from search engines.

In fig. 5-6 the results of the work of the developed systems in the form of charts are presented, from which it follows that in the presence of all types of IA significantly increases the volume of visits and unique users.

The fig. 5 presents a result of statistical analysis of the fotoghalereja-vysocjkykh.com functioning. The fig. 5a shows a dependence of selling commercial content from visiting information resource fotoghalerejavysocjkykh.com. The fig. $5 \mathrm{~b}$ shows the correlation of the visit to the information resource of fotoghalerejavysocjkykh.com and the implementation of commercial content, depending on the application of methods for processing commercial content. The fig. 6 presents the result of statistical analysis of the Victana functioning. The fig. 6a shows the statistical distribution of visits to the information resource victana.lviv.ua and the implementation of commercial content. The fig. $6 \mathrm{~b}$ shows

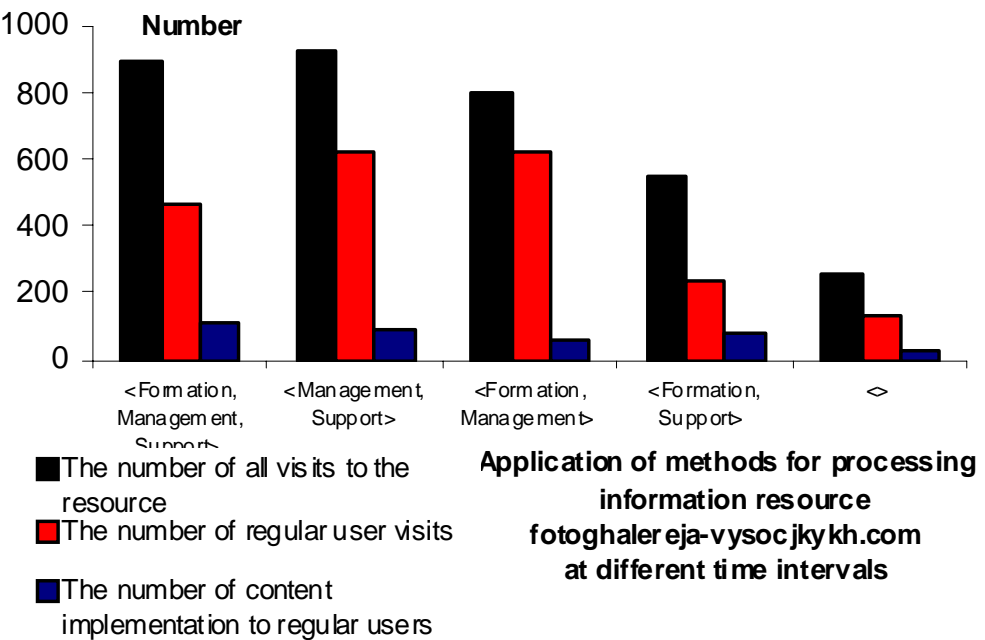

Figure 5 - Statistical analysis of the fotoghalereja-vysocjkykh.com functioning: a - diagram of relations; $b$ - graph of dependency 
a dependence of the visit to the information resource victana.lviv.ua and the implementation of commercial content from the connection of software for the processing of information content. The service of the statistics of visits to the information resource of the SEC allows us to estimate the increase in the volume of sales of content from the direct proportional dependence of the increase in the number of visits to the information resource, the number of regular users, the promise of marketing activities (Fig. 7a). The fig. $7 \mathrm{~b}$ presents a mathematical expectation of commercial content realization through the information resource. The fig. 8 shows a result of statistical analysis of the information resource victana.lviv.ua visiting pages per session.

\section{DISCUSSION}

The presence of different types of IA in SEC increases in sales of goods and / or services a regular user of $9 \%$, the active involvement of unique visitors, potential users and expanding the boundaries of the target and regional audience by $11 \%$, page views by $12 \%$, time of visit information resources on $7 \%$. So cumulative (fig. 9a) and median filtering (fig. 9b) for information resource victana.lviv.ua visit pages per session is shown in Fig. 9.

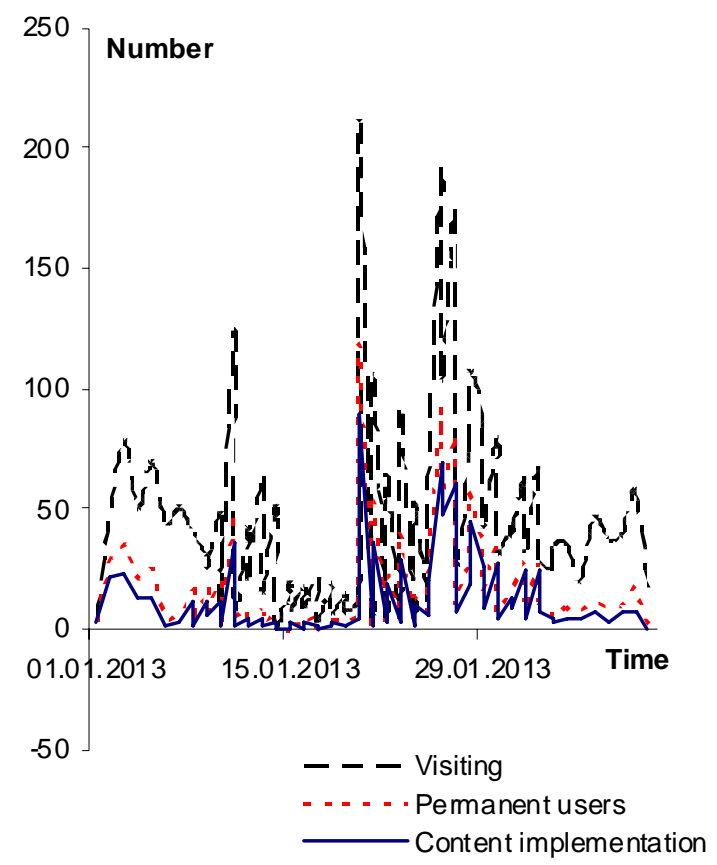

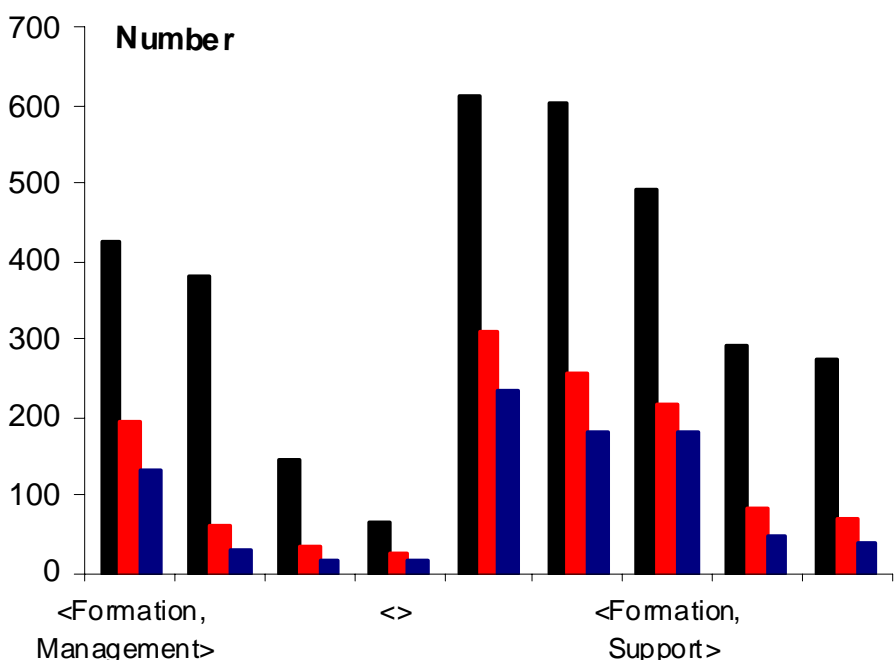

Visiting the target resource information resource

Visiting permanent users of information and resources

Realization of commercial content among permanent users
Connected software means of processing commercial content

Figure 6 - Statistical analysis of the Victana functioning: $a$ - diagram of relations; $b$ - graph of dependency

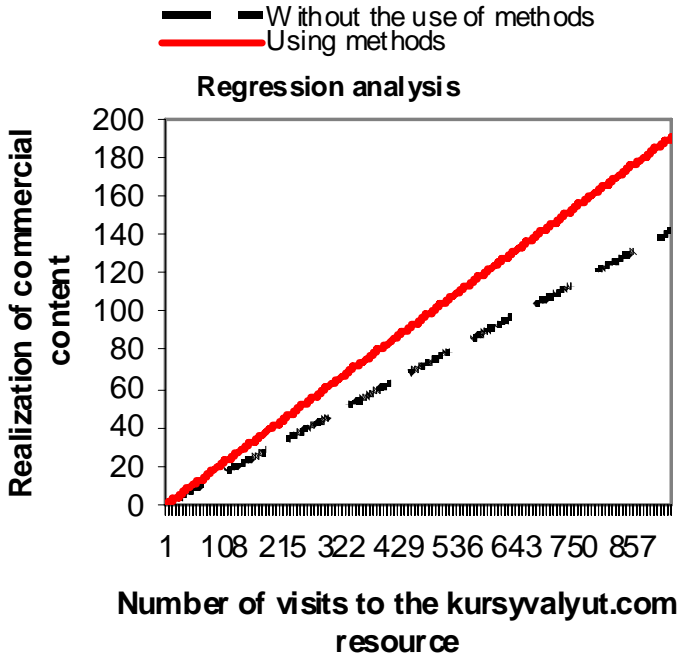

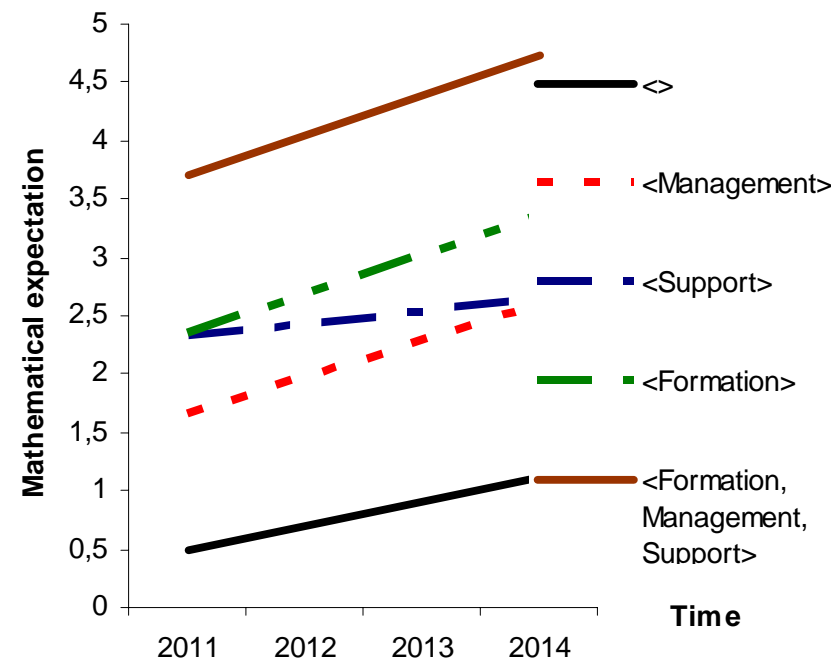

b

Figure 7 - Regression analysis of the increase in content sales: a - diagram of regression analysis for visits to the kursyvalyut.com resource; $b$ - diagram of mathematical expectation of commercial content realization through the information resource 


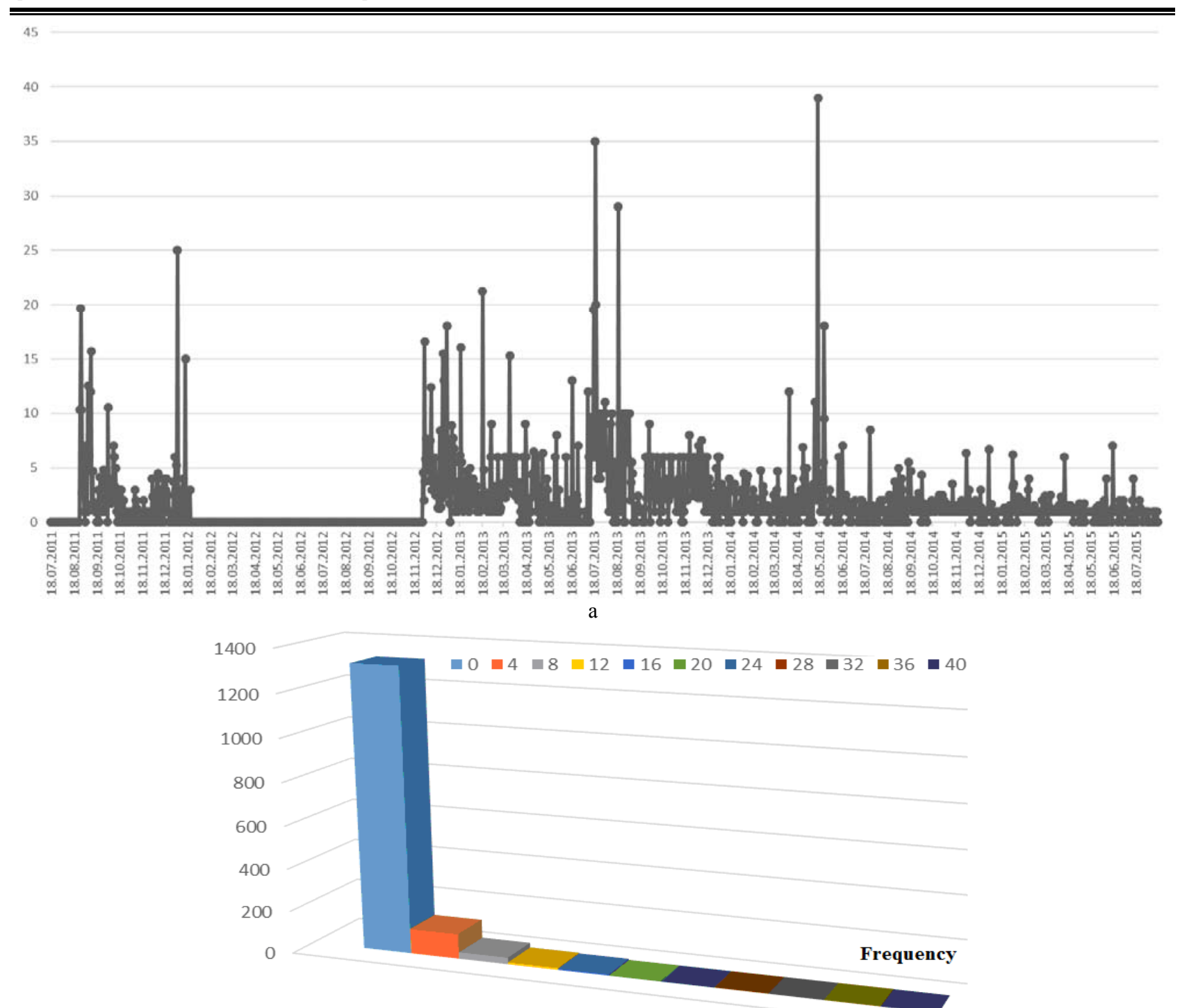

b

Figure 8 - For information resource victana.lviv.ua visiting pages per session: $a$ - diagram of relations; $b$ - graph of dependency
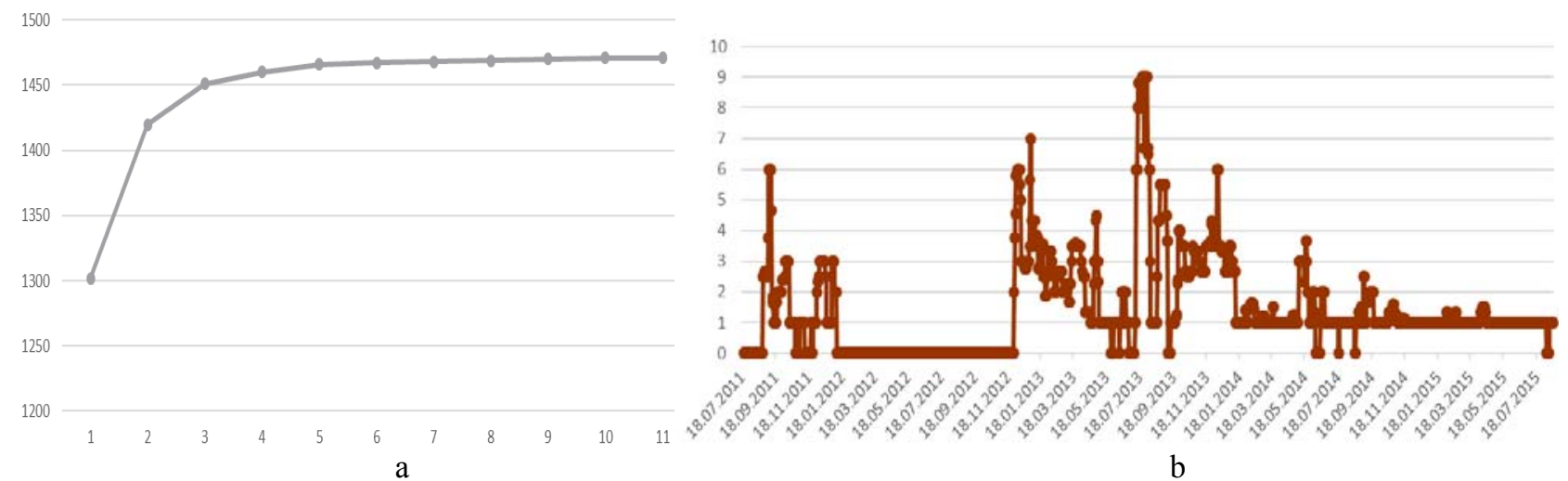

Figure 9 - Statistical analysis of the visiting information resource victana.lviv.ua: $a$ - cumulate of relations; $b$ - graph of Median Filtering

For an agglomeration hierarchical cluster analysis, it is advisable to choose the strategy of the "closest neighbor" for unification (since the proximity matrix consists of only 5 objects). The distance between the two groups is defined as the distance between the two closest elements (C) Berko A. Y., Vysotska V. A., Lytvyn V. V., Naum O. M., 2018 DOI 10.15588/1607-3274-2018-4-14 of these groups (Fig. 10). This strategy is monotonous and greatly compresses the space of signs.

We will now analyze the information resource tatjana.in.ua from the IA type B2C (Fig. 11-12). 
e-ISSN 1607-3274 Радіоелектроніка, інформатика, управління. 2018. № 4 p-ISSN 2313-688X Radio Electronics, Computer Science, Control. 2018. № 4

\begin{tabular}{|c|c|c|c|c|c|}
\hline \hline & $\mathbf{2 0 1 1}$ & $\mathbf{2 0 1 2}$ & $\mathbf{2 0 1 3}$ & $\mathbf{2 0 1 4}$ & $\mathbf{2 0 1 5}$ \\
\hline $\mathbf{2 0 1 1}$ & 0 & 1,5 & 2,1 & 2,3 & 2 \\
\hline $\mathbf{2 0 1 2}$ & 1,5 & 0 & 2,4 & 1,6 & 1,8 \\
\hline $\mathbf{2 0 1 3}$ & 2,1 & 2,4 & 0 & 2 & 2,8 \\
\hline $\mathbf{2 0 1 4}$ & 2,3 & 1,6 & 2 & 0 & 2,4 \\
\hline $\mathbf{2 0 1 5}$ & 2 & 1,8 & 2,8 & 2,4 & 0 \\
\hline
\end{tabular}

\begin{tabular}{|c|c|c|c|c|}
\hline & {$[\mathbf{2 0 1 1 , 2 0 1 2}]$} & $\mathbf{2 0 1 3}$ & $\mathbf{2 0 1 4}$ & $\mathbf{2 0 1 5}$ \\
\hline$[\mathbf{2 0 1 1 , 2 0 1 2}]$ & 0 & 2,1 & 1,6 & 1,8 \\
\hline $\mathbf{2 0 1 3}$ & 2,1 & 0 & 2 & 2,8 \\
\hline $\mathbf{2 0 1 4}$ & 1,6 & 2 & 0 & 2,4 \\
\hline $\mathbf{2 0 1 5}$ & 1,8 & 2,8 & 2,4 & 0 \\
\hline
\end{tabular}

\begin{tabular}{|c|c|c|c|}
\hline & {$[\mathbf{2 0 1 1 , 2 0 1 2 , 2 0 1 4 ]}$} & $\mathbf{2 0 1 3}$ & $\mathbf{2 0 1 5}$ \\
\hline$[\mathbf{2 0 1 1 , 2 0 1 2 , 2 0 1 4 ]}$ & 0 & 2 & 1,8 \\
\hline $\mathbf{2 0 1 3}$ & 2 & 0 & 2,8 \\
\hline $\mathbf{2 0 1 5}$ & 1,8 & 2,8 & 0 \\
\hline
\end{tabular}

\begin{tabular}{|c|c|c|}
\hline & {$[2011,2012,2014,2015$} & 2013 \\
\hline$[2011,2012,2014,2015]$ & 0 & 2 \\
\hline 2013 & 2 & 0 \\
\hline
\end{tabular}

a

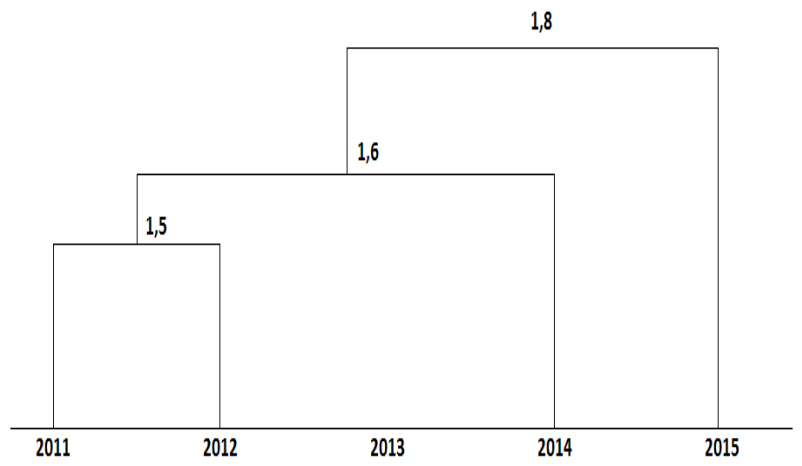

b

Figure 10 - Statistical analysis of the visiting resource victana.lviv.ua: a - stages of the "closest neighbor" strategy; $\mathrm{b}$ - dendrogram of dependency

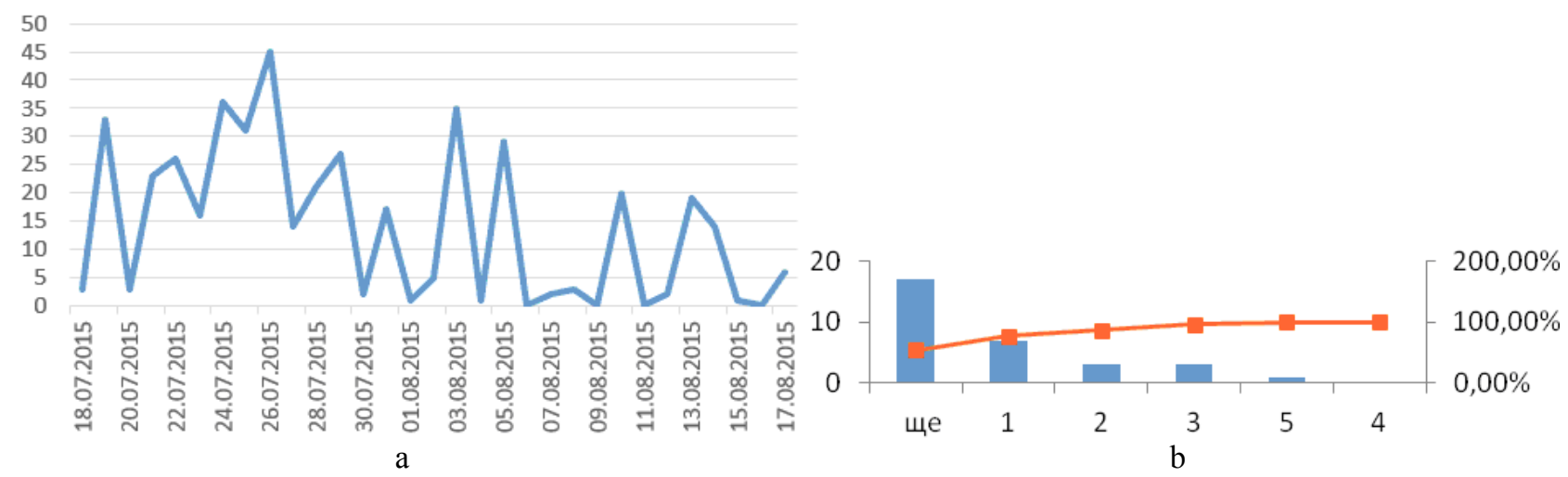

Figure 11 - Statistical analysis of the visits on the information resource tatjana.in.ua from the IA type B2C: a - schedule of relations; $\mathrm{b}$ - cumulative of dependency

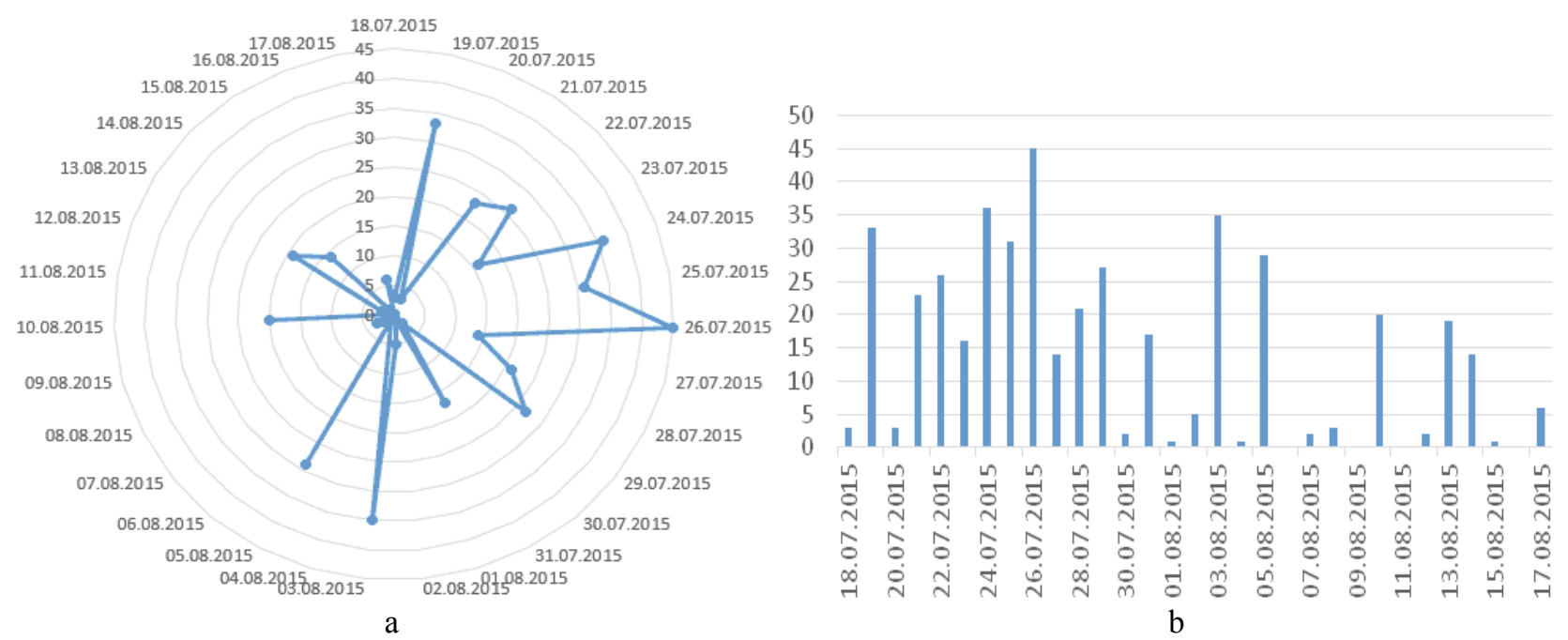

Figure 12 - Statistical analysis of the visits on the information resource tatjana.in.ua from the IA type B2C: a - visit schedule of relations; $b$ - histogram cumulative of dependency 
The fig. 11a shows the time line diagram of visits on the information resource tatjana.in.ua from the IA type $\mathrm{B} 2 \mathrm{C}$. The fig. $11 \mathrm{~b}$ shows cumulative diagram of visits on the information resource tatjana.in.ua from the IA type $\mathrm{B} 2 \mathrm{C}$. The site visits are going down in time for the information resource of the IA type B2C. This shows on fig. 12 also. Fig. 12a shows the time line diagram of visits on the information resource of the IA type B2C. Fig. $12 b$ shows the histogram cumulative of visits on the information resource tatjana.in.ua from the IA type B2C. In fig. 13 is dendrogram, of visit on tatjana.in.ua.

In fig. 14 gives the result of finding the trend in a time series of smoothing methods for the information resource tatjana.in.ua without IA. Fig. 14a shows original data on smoothing time line diagram for the visit on the information resource of the IA type B2C. Fig. 14b shows smoothing time line diagram for the visit on the information resource of the IA type B2C where smoothing coefficient $w=3$. Fig. $14 \mathrm{c}$ shows smoothing time line diagram for the visit on the information resource of the IA type B2C where smoothing coefficient $w=5$.

\section{CONCLUSIONS}

The mathematical support and method of action planning of IA based on adaptive ontologies are developed. This method can be used to effectively operate IA in a competitive environment of the SEC, which is modeled by Boyd's loop. Adaptive ontology is used to plan IA actions. To this end, we have added two scalar quantities (the importance of concepts and relationships) that are used to find an effective way to implement the IA plan in a generally accepted three-element tuple that defines an ontology (a set of concepts, relationships, and

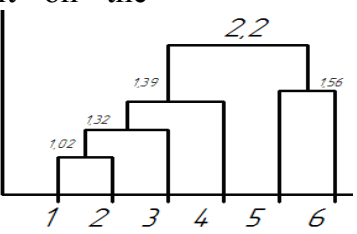

Figure 13 - Visit the dentogram tatjana.in.ua
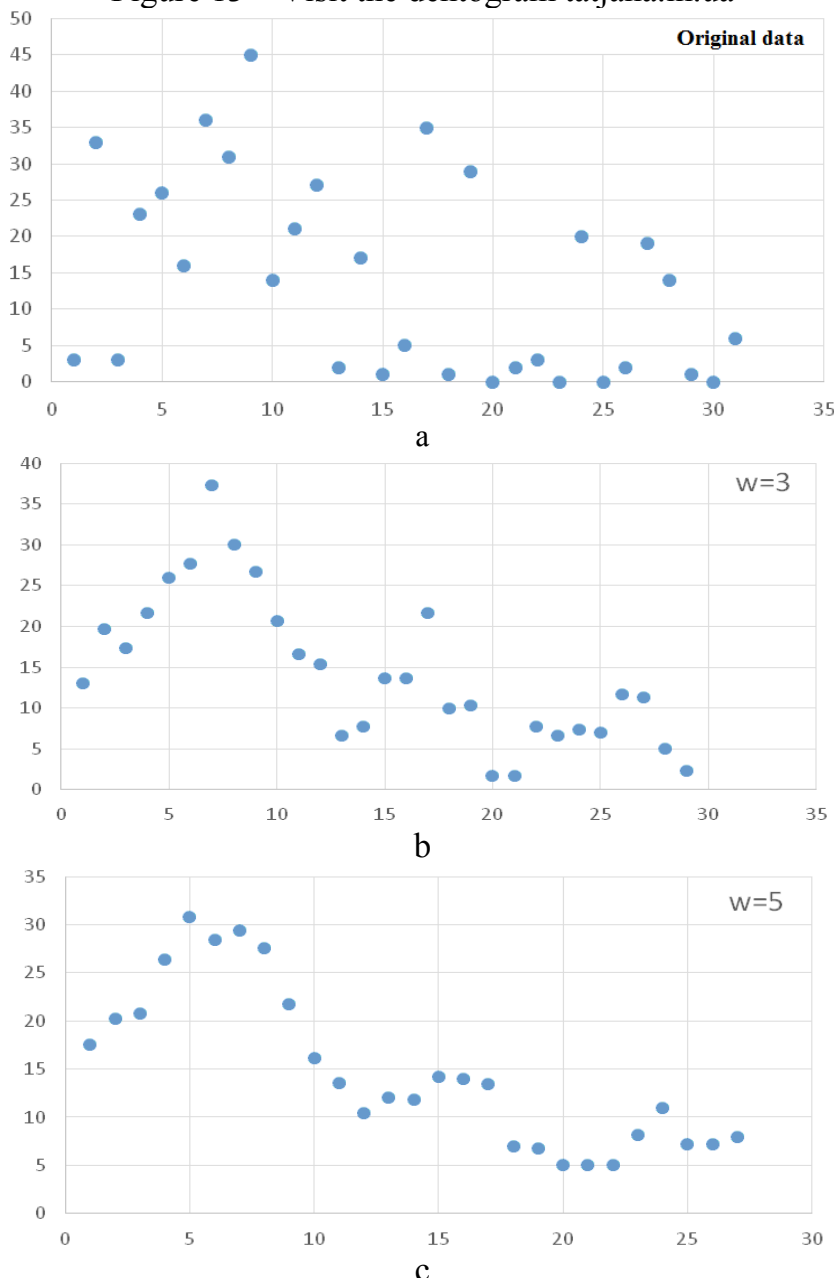

Figure 14 - Smoothing schedule for the visit on the information resource of the IA type B2C: a - original data on smoothing time line diagram; $\mathrm{b}$ - smoothing time line diagram where smoothing coefficient $w=3 ; \mathrm{c}$ - smoothing time line diagram where smoothing coefficient $w=5$ 
their interpretation). Such an assessment of the ontology elements allows to reduce the task of planning IA actions in a competitive environment to the task of dynamic programming. The scientific novelty of the article is the development of a method and mathematical support for the use of ontologies at the stage of Boyd's loop orientation for constructing an effective IA action plan for SEC. The presence of all types of IAs in the SEC leads to an increase in the volumes of sales of goods and / or services to a constant user by $9 \%$, the active involvement of unique visitors, potential users and the expansion of the target and regional audience by $11 \%$, revised pages by $12 \%$, time of information resource visits to $7 \%$.

\section{ACKNOWLEDGEMENTS}

The work was performed within the framework of the state budget theme "Methods and means of functioning of decision-support systems on the basis of ontologies" (ID: 839 2017-05-15 09:20:01 (2459-315)). The research was carried out within the framework of joint research of the department of information systems and networks of Lviv Polytechnic National University on the topic "Research, development and implementation of intelligent distributed information technologies and systems based on database resources, data warehouses, data spaces and knowledge to accelerate the processes of forming modern information society". Scientific researches were also carried out within the framework of the research topics of the Information System and Network Department at Lviv Polytechnic National University on the topic "Development of intellectual distributed systems based on the ontological approach for the integration of information resources".

\section{REFERENCES}

1. Ivlev A. A. Osnovy teorii Boyda. Napravleniya razvitiya, primeneniya i realizatsii. Moscow, 2008, 68 p.

2. Gruber T. A translation approach to portable ontologies, Knowledge Acquisition, 1993, No. 5 (2), pp. 199-220.

3. Guarino N. Formal Ontology, Conceptual Analysis and Knowledge Representation, International Journal of Human-Computer Studies, 1995, No. 43(5-6), pp. 625-640.

4. Sowa J. Conceptual Graphs as a universal knowledge representation, In: Semantic Networks in Artificial Intelligence, Spec. Issue of An International Journal Computers \& Mathematics with Applications. (Ed. F. Lehmann), 1992, Vol. 23, No. 2-5, Part 1, pp.75-95.

5. Vysotska V., Chyrun L. Analysis features of information resources processing Process, Computer Sciences and Information Technologies (CSIT), International Conference, Lviv, 14-17 September, 2015, proceedings. Lviv, IEEE, 2015, pp. 124-128

6. Vysotska V., Hasko R., Kuchkovskiy V. Process analysis in electronic content commerce system, Computer Sciences and Information Technologies (CSIT), International Conference, Lviv, 14-17 September, 2015, proceedings. Lviv, IEEE, 2015, pp. 120-123.

7. Mykich K., Burov Y. Algebraic model for knowledge representation in situational awareness systems, Computer Sciences and Information Technologies (CSIT),
International Conference, Lviv, 06-10 September, 2016, proceedings. Lviv, IEEE, 2016, pp. 165-167.

8. Mykich K., Burov Y. Uncertainty in situational awareness systems, Modern Problems of Radio Engineering, Telecommunications and Computer Science (TCSET), XIIIth International Conference, Lviv, 23-26 February, 2016, proceedings. Lviv, IEEE, 2016, pp. 729-732.

9. Mykich K., Burov Y. Algebraic Framework for Knowledge Processing in Systems with Situational Awareness, Advances in Intelligent Systems and Computing. Springer, pp. 217-228.

10. Vysotska V. Linguistic Analysis of Textual Commercial Content for Information Resources Processing, Modern Problems of Radio Engineering, Telecommunications and Computer Science (TCSET), XIIIth International Conference, Lviv, 23-26 February, 2016, proceedings. Lviv, IEEE, 2016, pp. 709-713.

11. Mykich K., Burov Y. Research of uncertainties in situational awareness systems and methods of their processing, EasternEuropean Journal of Enterprise Technologies, 2016, Vol. 1(79), pp. 19-26.

12. Su J., Vysotska V., Sachenko A., Lytvyn V., Burov Y. Information resources processing using linguistic analysis of textual content, Intelligent Data Acquisition and Advanced Computing Systems: Technology and Applications (IDAACS), 9th IEEE International Conference, Bucharest, Romania, 21-23 September, 2017, proceedings. Bucharest, IEEE, 2017, pp. 573-578.

13. Vysotska V., Chyrun L., Chyrun L. The Commercial Content Digest Formation and Distributional Process, Computer Sciences and Information Technologies (CSIT), International Conference, Lviv, 06-10 September, 2016, proceedings. Lviv, IEEE, 2016, pp. 186-189.

14. Bisikalo O. V., Vysotska V. A. Identifying keywords on the basis of content monitoring method in ukrainian texts, Radio Electronics, Computer Science, Control, 2016, Vol. 1(36), pp. 74-83.

15. Bisikalo O. V., Vysotska V. A. Sentence syntactic analysis application to keywords identification Ukrainian texts, Radio Electronics, Computer Science, Control, 2016, Vol. 3(38), pp. 54-65.

16. Lytvyn V., Bobyk I., Vysotska V. Application of algorithmic algebra system for grammatical analysis of symbolic computation expressions of propositional logic, Radio Electronics, Computer Science, Control, 2016, Vol. 4(39), pp. 54-67.

17. Alieksieieva K., Berko A., Vysotska V. Technology of commercial web-resource management based on fuzzy logic, Radio Electronics, Computer Science, Control, 2015, Vol. 3(34), pp. 71-79.

18. Vysotska V., Chyrun L., Chyrun L. Information Technology of Processing Information Resources in Electronic Content Commerce Systems, Computer Sciences and Information Technologies (CSIT), International Conference, Lviv, 06-10 September, 2016, proceedings. Lviv, IEEE, 2016, pp. 212222.

19. Korobchinsky M. Vysotska V., Chyrun L., Chyrun L. Peculiarities of Content Forming and Analysis in Internet Newspaper Covering Music News, Computer Sciences and Information Technologies (CSIT), International Conference, Lviv, 11-14 September, 2017, proceedings. Lviv, IEEE, 2017, pp. 52-57.

20. Naum O. Chyrun L., Kanishcheva O., Vysotska V. Intellectual System Design for Content Formation, Computer Sciences and Information Technologies (CSIT), 
International Conference, Lviv, 11-14 September, 2017, proceedings. Lviv, IEEE, 2017, pp. 131-138.

21. Gonçalves M.A. Fox E.A., nWatson L. T., Kipp N. A. Streams, Structures, Spaces, Scenarios, Societies (5S): A Formal Model for Digital Libraries, ACM Transactions on Information Systems (TOIS), 2004, Vol. 22(2), pp. 270-312.

22. Gonçalves M. A. Streams, Structures, Spaces, Scenarios, and Societies (5S): A Formal Model for Digital Library Framework and Its Applications, PhD thesis, Virginia Polytechnic Institute and State University, November 2004. https://pdfs.semanticscholar.org/fef2/c2c42328ccbeefe3705a 99b0ae9462749bd6.pdf.

23. Pérez A., Enrech M. Defining library services for a virtual community, Centre for research in Library and Information Management (CERLIM), Libraries Without Walls Conference, Lesvos, Greece, 10-14 September 1999, proceedings. London, Library Association, pp. 98-109.

24. Pérez A., Enrech M. Virtual Library Services for a Virtual University: User-Oriented Virtual Sites in an Open Library, Wiring the ivory tower, linking universities across europe (EADTU) : Millenium conference, Paris, 28-30 September 2001 : proceedings. Paris, Universitat Oberta de Catalunya. Access mode

http://openaccess.uoc.edu/webapps/o2/handle/10609/318

25. Stoffle Carla J. The Emergence of Education and Knowledge Management as Major Functions of the Digital Library, Follet Lecture Series, Consulted 22nd May 2000, http://www.ukoln.ac.uk/services/papers/follett/stoffle/paper. html.

26. Rashkevych Y., Peleshko D., Vynokurova O., Izonin I., Lotoshynska N. Single-frame image super-resolution based on singular square matrix operator, Electrical and Computer Engineering (UKRCON), 1th Ukraine Conference, Kyiv Ukraine 29 May-2 June 2017, proceedings. Kyiv, IEEE, pp. 944-948.

27. Tkachenko R., Tkachenko P., Izonin I., Tsymbal Y. Learning-based image scaling using neural-like structure of geometric transformation paradigm, Studies in Computational Intelligence, 2018, Vol. 730, SpringerVerlag, pp. 537-565.

28. Maksymiv O., Rak T., Peleshko D. Video-based Flame Detection using LBP-based Descriptor: Influences of Classifiers Variety on Detection Efficiency, International Journal of Intelligent Systems and Applications, 2017, Vol. 9(2), pp. 42-48

29. Peleshko D., Rak T., Izonin I. Image Superresolution via Divergence Matrix and Automatic Detection of Crossover, International Journal of Intelligent Systems and Application, 2016, Vol. 8(12), pp. 1-8.

30. Chernukha O., Bilushchak Y.Mathematical modeling of random concentration field and its second moments in a semispace with erlangian disrtibution of layered inclusions, Task Quarterly, 2016, Vol. 20(3), pp. 295-334.
31. Rusyn B., Lutsyk O., Lysak O., Lukeniuk A., Pohreliuk L. Lossless Image Compression in the Remote Sensing Applications, Data Stream Mining \& Processing (DSMP) : First International Conference, Lviv, 23-27 August, 2016, proceedings. 2016, Lviv, IEEE, pp. 195-198.

32. Kowalik D. Polish vocational competence standards for the needs of audult education and the Europen labour market, Advanced Information Engineering and Education Science (ICAEES) : International Conference, China, December 1920, 2013, proceedings. Beijing, IEEE, 2013, pp. 95-98.

33. Zhezhnych P., Markiv O. Linguistic Comparison Quality Evaluation of Web-Site Content with Tourism Documentation Objects, Advances in Intelligent Systems and Computing, 2018, Vol. 689, pp. 656-667.

34. Mobasher B. Data mining for web personalization, The adaptive web, Springer, 2007, pp. 90-135.

35. Dinucă C. E. Ciobanu D. Web Content Mining. In: University of Petrosani, Economics, 2012, P. 85.

36. Xu G. Y. Zhang, L. Li Web content mining / G. Xu, // Web Mining and Social Networking, 2011, Springer, pp. 71-87.

37. Ganesh J.A. A Comparative Study of Stemming Algorithms, International Journal Comp. Tech., 2011, pp. 1930-1938. Access:

https://pdfs.semanticscholar.org/1c0c/0fa35d4ff8a2f925eb95 5e48d655494bd167.pdf

38. Khomytska I., Teslyuk V. The Method of Statistical Analysis of the Scientific, Colloquial, Belles-Lettres and Newspaper Styles on the Phonological Level, Advances in Intelligent Systems and Computing. 2017, Vol. 512, pp. 149-163.

39. Davydov M., Lozynska O. Mathematical Method of Translation into Ukrainian Sign Language Based on Ontologies, Advances in Intelligent Systems and Computing, 2018, Vol. 689, pp. 89-100.

40. Khomytska I., Teslyuk V. Specifics of Phonostatistical Structure of the Scientific Style in English Style System, Computer Sciences and Information Technologies (CSIT) : International Conference, Lviv, 06-10 September, 2016, proceedings. Lviv, IEEE, 2016, pp. 129-131.

41. Davydov M., Lozynska O. Information System for Translation into Ukrainian Sign Language on Mobile Devices, Computer Sciences and Information Technologies (CSIT), International Conference, Lviv, 11-14 September, 2017, proceedings. Lviv, IEEE, 2017, pp. 4851 .

42. Davydov M., Lozynska O. Linguistic Models of Assistive Computer Technologies for Cognition and Communication, Computer Sciences and Information Technologies (CSIT), International Conference, Lviv, 11-14 September, 2017, proceedings. Lviv, IEEE, 2017, pp. 171-175.

Received 14.05.2018 Accepted 20.06.2018.

\section{УДК 004.9}

\section{ПЛАНУВАННЯ ДІЯЛЬНОСТІ ІНТЕЛЕКТУАЛЬНИХ АГЕНТІВ В СИСТЕМАХ ЕЛЕКТРОННОЇ КОМЕРЦІЇ}

Берко А. Ю. - д-р техн. наук, професор, професор кафедри «Інформаційні системи та мережі», Національний університет «Львівська політехніка», Львів, Україна.

Висоцька В. А. - канд. техн. наук, професор, доцент кафедри «Інформаційні системи та мережі», Національний університет «Львівська політехніка», Львів, Україна.

Литвин В. В. - д-р техн. наук, професор, завідувач кафедри «Інформаційні системи та мережі», Національний університет «Львівська політехніка», Львів, Україна. 
Наум О. М. - асистент кафедри «Інформаційні системи і технології», Дрогобицький державний педагогічний університет імені Івана Франка, Дрогобич, Україна.

\section{АНОТАЦІЯ}

Актуальність. Сьогодні електронна комерція $є$ одним 3 найактивніших та найбільш перспективних сегментів глобальної економіки, для якого характерним є стале зростання обсягів та активне вдосконалення засобів $\mathrm{i}$ технологій. Інтелектуалізація систем електронної комерції сьогодні $\epsilon$ одним 3 основних трендів їх розвитку та ефективного функціонування в конкурентному середовищі. Одним з найперспективніших засобів вирішення цієї категорії задач $\mathrm{e}$ використання інтелектуальних агентів (IA). Сучасний підхід до моделювання процесу підтримки прийняття рішень, зокрема, в електронній комерції використовує принцип петлі Бойда, який передбачає багаторазове повторення циклу 3 чотирьох послідовних взаємопов'язаних процесів (етапів): спостереження - орієнтація - прийняття рішення - дія. Згідно із гіпотезою Бойда - вища швидкість виконання циклу і точність оцінок етапів циклу забезпечує перевагу над конкурентом.

Метою дослідження $є$ розроблення засобів ефективного планування дій інтелектуальних агентів систем електронної комерції в конкурентному середовищі на основі онтологій, та зведення задачі планування дій інтелектуальних агентів до задачі динамічного програмування.

Метод. Розроблено математичне забезпечення та метод планування дій IA на основі адаптивних онтологій. Цей метод можна використати для ефективного функціонування IA у конкурентному середовищі СЕК, яке моделюється петлею Бойда. Для планування дій IA використано адаптивну онтологію. 3 цією метою у загальноприйнятий трьохелементний кортеж, який задає онтологію (множина понять, відношень та їх інтерпретація), нами додано дві скалярні величини (важливість понять та відношень), які використовуються для пошуку ефективного шляху реалізації плану IА. Така оцінка елементів онтології дає змогу звести задачу планування дій IА в конкурентному середовищі до задачі динамічного програмування.

Результати. У статті побудовано модель планування дій інтелектуальних агентів систем електронної комерції 3 використанням онтологічного підходу. Розроблено метод оцінки дій інтелектуальних агентів на основі адаптивних онтологій. Така оцінка дає змогу звести задачу планування дій до задачі динамічного програмування.

Висновки. Аналіз результатів дій IA дозволяе визначити причин формування цільової аудиторії за набором характеристик функціонування СЕК. Регулюючи тематичний набір контенту, його унікальність, оперативність його формування та адекватне управління ним згідно індивідуальних потреб постійного користувача, можна моделювати межі цільової соціальної аудиторії та кількість унікальних відвідувачів з пошукових систем. На рис. 5-6 подані результати роботи розроблених систем у вигляді графіків, з яких випливає, що при наявності всіх типів ІА суттєво збільшується обсяг відвідувань та унікальних користувачів.

КЛЮЧОВІ СЛОВА: інтелектуальний агент, онтологія, планування, електронна комерція.

\section{УДК 004.9}

\section{ПЛАНИРОВАНИЕ ДЕЯТЕЛЬНОСТИ ИНТЕЛЛЕКТУАЛЬНЫХ АГЕНТОВ В СИСТЕМАХ ЭЛЕКТРОННОЙ КОММЕРЦИИ}

Берко А. Ю. - д-р техн. наук, профессор, профессор кафедры «Информационные системы и сети», Национальный университет «Львовская политехника», Украина.

Высоцкая В. А. - канд. техн. наук, профессор, доцент кафедры «Информационные системы и сети», Национальный университет «Львовская политехника», Украина.

Лытвын В. В. - д-р техн. наук, профессор, заведующий кафедрой «Информационные системы и сети», Национальный университет «Львовская политехника», Украина.

Наум О. М. - ассистент кафедры «Информационные системы и технологии», Дрогобычский государственный педагогический университет имени Ивана Франко, Дрогобыч, Украина.

\section{АНОТАЦИЯ}

Актуальность. Сегодня электронная коммерция является одним из самых активных и наиболее перспективных сегментов глобальной экономики, для которого характерно устойчивый рост объемов и активное совершенствование средств и технологий. Интеллектуализация систем электронной коммерции сегодня является одним из основных трендов их развития и эффективного функционирования в конкурентной среде. Одним из самых перспективных способов решения этой категории задач является использование интеллектуальных агентов (ИА). Современный подход к моделированию процесса поддержки принятия решений, в частности, в электронной коммерции использует принцип петли Бойда, который предусматривает многократное повторение цикла из четырех последовательных взаимосвязанных процессов (этапов): наблюдение - ориентация - принятие решения - действие. Согласно гипотезе Бойда - высокая скорость выполнения цикла и точность оценок этапов цикла обеспечивает преимущество над конкурентом.

Целью исследования является разработка средств эффективного планирования действий интеллектуальных агентов систем электронной коммерции в конкурентной среде на основе онтологий, и сведения задачи планирования действий интеллектуальных агентов к задаче динамического программирования.

Метод. Разработаны математическое обеспечение и метод планирования действий ИА на основе адаптивных онтологий. Этот метод можно использовать для эффективного функционирования ИА в конкурентной среде СЕК, которое моделируется петлей Бойда. Для планирования действий ИА использовано адаптивную онтологию. С этой целью в общепринятый Трехэлементный кортеж, который задает онтологию (множество понятий, отношений и их интерпретация), нами добавлено две скалярные величины (важность понятий и отношений), которые используются для поиска 
эффективного пути реализации плана ИА. Такая оценка элементов онтологии позволяет свести задачу планирования действий ИА в конкурентной среде к задаче динамического программирования.

Результаты. В статье построена модель планирования действий интеллектуальных агентов систем электронной коммерции с использованием онтологического подхода. Разработан метод оценки действий интеллектуальных агентов на основе адаптивных онтологий. Такая оценка позволяет свести задачу планирования действий в задачи динамического программирования.

Выводы. Анализ результатов действий ИА позволяет определить причин формирования целевой аудитории по набору характеристик функционирования СЕК. Регулируя тематический набор контента, его уникальность, оперативность его формирования и адекватное управление им в соответствии индивидуальных потребностей постоянного пользователя, можно моделировать пределы целевой социальной аудитории и количество уникальных посетителей из поисковых систем. На рис. 5-6 представлены результаты работы разработанных систем в виде графиков, из которых следует, что при наличии всех типов ИА существенно увеличивается объем посещений и уникальных пользователей.

КЛЮЧЕВЫЕ СЛОВА: интеллектуальный агент, онтология, планирование, электронная коммерция.

\section{ЛІТЕРАТУРА/ ЛИТЕРАТУРА}

1. Ивлев А. А. Основы теории Бойда. Направления развития, применения и реализации. М. :, 2008. - 68 с.

2. Gruber T. A translation approach to portable ontologies / T.Gruber // Knowledge Acquisition. - 1993. - № 5 (2). P. 199-220.

3. Guarino N. Formal Ontology, Conceptual Analysis and Knowledge Representation / N. Guarino // International Journal of Human-Computer Studies. - 1995. - № 43 (56). - P. 625-640.

4. Sowa J. Conceptual Graphs as a universal knowledge representation / J. Sowa // In: Semantic Networks in Artificial Intelligence, Spec. Issue of An International Journal Computers \& Mathematics with Applications. (Ed F. Lehmann). - 1992. - Vol. 23, № 2-5, Part 1. - P. 75-95.

5. Vysotska V. Analysis features of information resources processing Process / V. Vysotska, L. Chyrun // Computer Sciences and Information Technologies (CSIT) : International Conference, Lviv, 14-17 September, 2015 : proceedings. - Lviv : IEEE, 2015. - P. 124-128

6. Vysotska V. Process analysis in electronic content commerce system / V. Vysotska, R Hasko., V. Kuchkovskiy // Computer Sciences and Information Technologies (CSIT) : International Conference, Lviv, 14-17 September, 2015 : proceedings. - Lviv : IEEE, 2015. - P. 120-123.

7. Mykich K. Algebraic model for knowledge representation in situational awareness systems / K. Mykich, Y. Burov // Computer Sciences and Information Technologies (CSIT) : International Conference, Lviv, 06-10 September, 2016 : proceedings. - Lviv : IEEE, 2016. - P. 165-167.

8. Mykich K. Uncertainty in situational awareness systems / K. Mykich, Y. Burov // Modern Problems of Radio Engineering, Telecommunications and Computer Science (TCSET) : XIIIth International Conference, Lviv, 23-26 February, 2016 : proceedings. - Lviv : IEEE, 2016. P. 729-732.

9. Mykich K. Algebraic Framework for Knowledge Processing in Systems with Situational Awareness / K. Mykich, Y. Burov // Advances in Intelligent Systems and Computing. - Springer. - P. 217-228.

10. Vysotska V. Linguistic Analysis of Textual Commercial Content for Information Resources Processing / V. Vysotska // Modern Problems of Radio Engineering, Telecommunications and Computer Science (TCSET) : XIIIth International Conference, Lviv, 23-26 February, 2016 : proceedings. - Lviv : IEEE, 2016. - P. 709-713.

11. Mykich K. Research of uncertainties in situational awareness systems and methods of their processing / K. Mykich, Y. Burov // EasternEuropean Journal of Enterprise Technologies. - Vol. 1(79). - 2016. - P. 19-26.
12. Information resources processing using linguistic analysis of textual content / [J. Su, V. Vysotska, A. Sachenko, V. Lytvyn, Y. Burov] // Intelligent Data Acquisition and Advanced Computing Systems: Technology and Applications (IDAACS) : 9th IEEE International Conference, Bucharest, Romania, 21-23 September, 2017 : proceedings. - Bucharest : IEEE, 2017. - P. 573-578.

13. Vysotska V. The Commercial Content Digest Formation and Distributional Process / V. Vysotska, L. Chyrun, L. Chyrun // Computer Sciences and Information Technologies (CSIT) : International Conference, Lviv, 06-10 September, 2016 : proceedings. - Lviv : IEEE, 2016. - P. 186-189.

14. Bisikalo O.V. Identifying keywords on the basis of content monitoring method in ukrainian texts / O. V. Bisikalo, V. A. Vysotska // Radio Electronics, Computer Science, Control. - 2016. - Vol. 1(36).- P. 74-83.

15. Bisikalo O. V. Sentence syntactic analysis application to keywords identification Ukrainian texts / O. V. Bisikalo, V. A. Vysotska // Radio Electronics, Computer Science, Control. - 2016. - Vol. 3(38). - P. 54-65.

16. Lytvyn V. Application of algorithmic algebra system for grammatical analysis of symbolic computation expressions of propositional logic / V. Lytvyn, I. Bobyk, V. Vysotska // Radio Electronics, Computer Science, Control. - 2016. Vol. 4(39). - P. 54-67.

17. Alieksieieva K. Technology of commercial web-resource management based on fuzzy logic / K. Alieksieieva, A. Berko, V. Vysotska // Radio Electronics, Computer Science, Control. - 2015. - Vol. 3(34). - P. 71-79.

18. Vysotska V. Information Technology of Processing Information Resources in Electronic Content Commerce Systems / V. Vysotska, L. Chyrun, L. Chyrun // Computer Sciences and Information Technologies (CSIT) : International Conference, Lviv, 06-10 September, 2016 : proceedings. - Lviv : IEEE, 2016. - P. 212-222.

19. Peculiarities of Content Forming and Analysis in Internet Newspaper Covering Music News / [M. Korobchinsky, V. Vysotska, L. Chyrun, L. Chyrun] // Computer Sciences and Information Technologies (CSIT) : International Conference, Lviv, 11-14 September, 2017 : proceedings. Lviv : IEEE, 2017. - P. 52-57.

20. Intellectual System Design for Content Formation / [O. Naum, L. Chyrun, O. Kanishcheva, V. Vysotska] // Computer Sciences and Information Technologies (CSIT) : International Conference, Lviv, 11-14 September, 2017 : proceedings. - Lviv : IEEE, 2017. - P. 131-138.

21. Streams, Structures, Spaces, Scenarios, Societies (5S): A Formal Model for Digital Libraries / [M. A. Gonçalves, E. A. Fox, L. T. nWatson, N. A. Kipp] // ACM Transactions on Information Systems (TOIS). - 2004. - Vol. 22(2). P. 270-312. 
22. Gonçalves M. A. Streams, Structures, Spaces, Scenarios, and Societies (5S): A Formal Model for Digital Library Framework and Its Applications / M. A. Gonçalves // PhD thesis, Virginia Polytechnic Institute and State University. November 2004.

https://pdfs.semanticscholar.org/fef2/c2c42328ccbeefe3705a 99b0ae9462749bd6.pdf.

23. Pérez A. Defining library services for a virtual community / A. Pérez, M. Enrech // Centre for research in Library and Information Management (CERLIM) : Libraries Without Walls Conference, Lesvos, Greece, 10-14 September 1999 : proceedings. - London : Library Association. - P. 98-109.

24. Pérez A. Virtual Library Services for a Virtual University: User-Oriented Virtual Sites in an Open Library / A. Pérez, M. Enrech // Wiring the ivory tower, linking universities across europe (EADTU) : Millenium conference, Paris, 2830 September 2001 : proceedings. - Paris : Universitat Oberta de Catalunya. - Access mode : http://openaccess.uoc.edu/webapps/o2/handle/10609/318.

25. Stoffle Carla J. The Emergence of Education and Knowledge Management as Major Functions of the Digital Library /Carla J. Stoffle // Follet Lecture Series. - Consulted 22nd May 2000.

http://www.ukoln.ac.uk/services/papers/follett/stoffle/paper. html.

26. Single-frame image super-resolution based on singular square matrix operator / [Y. Rashkevych, D. Peleshko, O. Vynokurova et al.] // Electrical and Computer Engineering (UKRCON) : 1th Ukraine Conference, Kyiv, Ukraine 29 May - 2 June 2017 : proceedings. - Kyiv : IEEE. - P. 944-948.

27. Learning-based image scaling using neural-like structure of geometric transformation paradigm / [R. Tkachenko, P. Tkachenko, I. Izonin, Y. Tsymbal] // Studies in Computational Intelligence. - 2018. - Vol. 730. - SpringerVerlag. - P. 537-565.

28. Maksymiv O. Video-based Flame Detection using LBPbased Descriptor: Influences of Classifiers Variety on Detection Efficiency / O. Maksymiv, T. Rak, D. Peleshko // International Journal of Intelligent Systems and Applications. - 2017. - Vol. 9(2). - P. 42-48.

29. Peleshko D. Image Superresolution via Divergence Matrix and Automatic Detection of Crossover / D. Peleshko, T. Rak, I. Izonin // International Journal of Intelligent Systems and Application. - 2016. - Vol. 8(12). - P. 1-8.

30. Chernukha O. Mathematical modeling of random concentration field and its second moments in a semispace with erlangian disrtibution of layered inclusions / O. Chernukha, Y. Bilushchak // Task Quarterly. - 2016. Vol. 20(3). - P. 295-334.

31. Lossless Image Compression in the Remote Sensing Applications / [B. Rusyn, O. Lutsyk, O. Lysak et al.] // Data Stream Mining \& Processing (DSMP) : First International
Conference, Lviv, 23-27 August, 2016 : proceedings. - Lviv : IEEE, 2016. - P. 195-198.

32. Kowalik D. Polish vocational competence standards for the needs of audult education and the Europen labour market / D. Kowalik // Advanced Information Engineering and Education Science (ICAEES) : International Conference, China, December 19-20, 2013 : proceedings. - Beijing: IEEE, 2013. - P. 95-98.

33. Zhezhnych P. Linguistic Comparison Quality Evaluation of Web-Site Content with Tourism Documentation Objects / P. Zhezhnych, O. Markiv // Advances in Intelligent Systems and Computing. - 2018. - Vol. 689. - P. 656-667.

34. Mobasher B. Data mining for web personalization / B. Mobasher // The adaptive web. -2007 , Springer. - P. 90135.

35. Dinucă C.E. Web Content Mining. In: University of Petroşani / C. E. Dinucă, D Ciobanu // Economics. - 2012. P. 85.

36. Xu G. Web content mining / G. Xu, Y. Zhang, L. Li // Web Mining and Social Networking. - 2011, Springer. - P. 7187.

37. Ganesh J.A. A Comparative Study of Stemming Algorithms / J. A. Ganesh // International Journal Comp. Tech. 2011. - P. 1930-1938. - $\quad$ Access: https://pdfs.semanticscholar.org/1c0c/0fa35d4ff8a2f925eb95 5e48d655494bd167.pdf.

38. Khomytska I. The Method of Statistical Analysis of the Scientific, Colloquial, Belles-Lettres and Newspaper Styles on the Phonological Level / I. Khomytska, V. Teslyuk // Advances in Intelligent Systems and Computing. - 2017. Vol. 512. - P. 149-163.

39. Davydov M. Mathematical Method of Translation into Ukrainian Sign Language Based on Ontologies / M. Davydov, O. Lozynska // Advances in Intelligent Systems and Computing. - 2018. - Vol. 689. - P. 89-100.

40. Khomytska I. Specifics of Phonostatistical Structure of the Scientific Style in English Style System/ I. Khomytska, V. Teslyuk // Computer Sciences and Information Technologies (CSIT) : International Conference, Lviv, 0610 September, 2016 : proceedings. - Lviv : IEEE, 2016. P. $129-131$.

41. Davydov M. Information System for Translation into Ukrainian Sign Language on Mobile Devices/ M. Davydov, O. Lozynska // Computer Sciences and Information Technologies (CSIT) : International Conference, Lviv, 1114 September, 2017 : proceedings. - Lviv : IEEE, 2017. P. 48-51.

42. Davydov M. Linguistic Models of Assistive Computer Technologies for Cognition and Communication / M. Davydov, O. Lozynska // Computer Sciences and Information Technologies (CSIT) : International Conference, Lviv, 11-14 September, 2017 : proceedings. Lviv : IEEE, 2017. - P. 171-175. 